\title{
Correction to: The differential diagnostic value of selected cardiovascular biomarkers in Takotsubo syndrome
}

\author{
Albert Topf ${ }^{1} \mathbb{D}$ - Moritz Mirna ${ }^{1} \cdot$ Vera Paar $^{1} \cdot$ Lukas J. Motloch $^{1}$ - Janine Grueninger ${ }^{1}$. Christiane Dienhart ${ }^{2}$. \\ Paul C. Schulze ${ }^{3} \cdot$ Mathias C. Brandt $^{1} \cdot$ Robert Larbig $^{4} \cdot$ Uta C. Hoppe ${ }^{1} \cdot$ Daniel Kretzschmar $^{3} \cdot$ Michael Lichtenauer $^{1}$
}

Published online: 2 December 2021

(c) The Author(s) 2021

\section{Correction to: Clinical Research in Cardiology https://doi.org/10.1007/s00392-021-01956-2}

In the original version of this article, the given and family names of Christiane Dienhart were interchanged. The original article has been corrected.

Open Access This article is licensed under a Creative Commons Attribution 4.0 International License, which permits use, sharing, adaptation, distribution and reproduction in any medium or format, as long as you give appropriate credit to the original author(s) and the source, provide a link to the Creative Commons licence, and indicate if changes were made. The images or other third party material in this article are included in the article's Creative Commons licence, unless indicated otherwise in a credit line to the material. If material is not included in the article's Creative Commons licence and your intended use is not permitted by statutory regulation or exceeds the permitted use, you will need to obtain permission directly from the copyright holder. To view a copy of this licence, visit http://creativecommons.org/licenses/by/4.0/.
The original article can be found online at https://doi.org/10.1007/ s00392-021-01956-2.

\section{Albert Topf}

albert.topf@hotmail.com

1 Clinic for Internal Medicine II, Department of Internal Medicine II, Paracelsus Medical University, University Hospital Salzburg, Paracelsus University Salzburg, Müllner Hauptstraße 48, 5020 Salzburg, Austria

2 Department of Internal Medicine I, Paracelsus Medical University, 5020 Salzburg, Austria

3 Division of Cardiology, Department of Internal Medicine I, University Hospital Jena, 07743 Jena, Germany

4 Devision of Cardiology, Hospital Maria Hilf Moenchengladbach, 41063 Möenchengladbach, Germany 